\title{
Corrigendum: Correction of Acknowledgments
}

\section{Transformation of Mature Osteoblasts into Bone Lining Cells and RNA Sequencing-Based Transcriptome Profiling of Mouse Bone during Mechanical Unloading}

\author{
A Ram Hong ${ }^{1, *}$, Kwangsoo Kim²,*, Ji Yeon Lee ${ }^{3}$, Jae-Yeon Yang ${ }^{3}$, Jung Hee Kim³, Chan Soo Shin ${ }^{3}$, Sang Wan Kim ${ }^{3}$ \\ ${ }^{1}$ Department of Internal Medicine, Chonnam National University Medical School, Gwangju; ${ }^{2}$ Seoul National University \\ Hospital Biomedical Research Institute; ${ }^{3}$ Department of Internal Medicine, Seoul National University College of Medicine, \\ Seoul, Korea
}

Endocrinol Metab 2020;35:456-69.

https://doi.org/10.3803/EnM.2020.35.2.456

In our recently published article, there were some wrong contents in the Acknowledgments section, which should be properly revised as follows.

\section{ACKNOWLEDGMENTS}

This work was supported by grants from the National Research Foundation of Korea (2017R1A2B2004708), and from PromisingPioneering Researcher Program through Seoul National University (2016).

We would like to apologize for any inconvenience or misunderstanding.

Corresponding author: Sang Wan Kim

Department of Internal Medicine, Seoul Metropolitan Government Seoul National University Boramae Medical Center, Seoul National University College of Medicine, 20 Boramae-ro 5-gil, Dongjak-gu, Seoul 07061, Korea Tel: +82-2-870-2223, Fax: +82-2-870-3863, E-mail: swkimmd@snu.ac.kr

*These authors contributed equally to this work.

\section{Copyright ( $\odot 2021$ Korean Endocrine Society}

This is an Open Access article distributed under the terms of the Creative Commons Attribution Non-Commercial License (https://creativecommons.org/ licenses/by-nc/4.0/) which permits unrestricted non-commercial use, distribution, and reproduction in any medium, provided the original work is properly cited. 